\title{
The Price of Un/Freedom: Indonesia's Colonial and Contemporary Plantation Labor Regimes
}

\author{
TANIA MURRAY LI
}

University of Toronto

Although often associated with colonial times, tropical plantations growing industrial crops such as rubber, sugar, and oil palm are once again expanding to meet global demands spurred by affluence. In just thirteen years, 20002013, the area of sugarcane expanded from 19 to 26 million hectares, mostly in Brazil. Rubber increased from 7 to 10 million hectares. Most impressive was the expansion of oil palm from 10 to 18 million hectares, mainly in Indonesia and Malaysia, which together produce 84 percent of the world supply. ${ }^{1}$ Palm oil has multiple uses: it is the cheapest domestic cooking oil, especially popular in India and China, and it is incorporated in scores of manufactured foods, detergents, and cosmetics. Roughly half the packaged products sold in supermarkets contain it. It can also be used as biofuel, and hence marketed as "green" and "renewable." Industry analysts expect global demand to double by 2040 , meaning that 36 million hectares - an area the size of Germany-could be covered with this crop. ${ }^{2}$

Renewed plantation expansion invites comparative reflection on how contemporary plantation labor regimes are like or unlike those of the colonial era. Plantation work has no intrinsic pleasures. It is dull, demanding, and often dangerous. It still involves remarkably basic tools: for rubber, tapping knives

Acknowledgments: Warm thanks to the CSSH editors and reviewers for their astute comments and provocations, and to Ben White, Rob Cramb, Michael Dove, Shozab Raza, Philip Kelly, Derek Hall, Peter Vandergeest, and Stephen Campbell for their input.

1 Crop areas by country and crop are drawn from: http://faostat3.fao.org/compare (last accessed 14 May 2016). On oil palm production in Malaysia and Indonesia, see Cramb and McCarthy 2016a and $2016 \mathrm{~b}$.

2 http://www.worldwildlife.org/pages/which-everyday-products-contain-palm-oil; and http:// greenpalm.org/about-palm-oil/what-is-palm-oil/what-is-palm-oil-used-for (both accessed 9 Jan. 2017). 
and collection cups; for oil palm, bush knives, plastic buckets, hand-pumped sprayers, and curved harvesting knives fixed to long poles. Although oil palm can be grown successfully by smallholders, most of the expansion is taking place on large-scale plantations of 5,000 to 40,000 hectares that employ thousands of wage workers. ${ }^{3}$ As in the colonial era, most of these workers are intra- or trans-national migrants.

Flagging colonial continuities, labor activists campaign against the reemergence of unfree labor and "modern forms of slavery." They highlight the predicament of plantation workers tricked into unfair contracts by unscrupulous brokers and rogue corporations, held captive, and "trafficked" across national borders. ${ }^{4}$ Paradoxically, labor activists also highlight the opposite problem: the casualization of plantation work. ${ }^{5}$ Ineffective labor laws and weak worker mobilization enable employers to avoid the costs of sustaining and reproducing workers daily or intergenerationally. Employers can buy labor power at will, treating it as a commodity like any other. Employers, in short, are too free. Workers faced with these conditions are too free as well, in the ironic sense noted by Marx: they are compelled to sell their labor on almost any terms. ${ }^{6}$

The plight of workers facing an excess of (market) freedom is occluded by campaigns to liberate trapped workers. As I will show, unfreedom is problematic, but freedom to sell one's labor at the market price is no panacea. What happens when no one wants to buy the commodity, labor? Or when the market price is below the cost of subsistence? Not only is an excess of (market) freedom terrifying for workers, it is damaging to society at large. As Polanyi stressed, treating labor power as a commodity to be used or discarded at will undermines the social relations that produce healthy, adequately socialized workers. ${ }^{7}$ Taken too far, commodification kills the goose that lays the golden egg. Polanyi argued that "society" would react to counter this destructive tendency, but this cannot be assumed. Not only do some employers find it in their interest to kill or maim the goose, when the cost of replacement is very low, but workers themselves may welcome the commodification of their labor power if it means they are free from the bonds of feudal or patriarchal control, and from slavery or indenture. ${ }^{8}$

\footnotetext{
3 In 2012, about 60 percent of Indonesia's oil palms were in large plantations, and 40 percent in independent and managed smallholdings. In the period 2005-2013, it was the plantation component of the total area that expanded more; in only two provinces in Sumatra (Bengkulu and Riau) did the increased area of smallholdings exceed that of plantations, and in Kalimantan the dominance of plantations is extreme ( $\mathrm{Li} 2015$ : 2-3).

4 Accenture 2012; Schuster Institute 2013. For a critique of the fixation on delinquent labor brokers at the expense of exploitative labor regimes, see McKeown 2012.

5 See Siagian et al. 2011; Wakker 2005; Marti 2008; Sinaga 2013.

6 Marx 1986.

7 Polanyi 1944: 73.

8 Fraser 2014: 550.
} 
Both freedom and unfreedom merit further critical, contextualized analysis, with a particular focus on the dynamics between them. I pursue this task here through a comparative study of Indonesia's colonial and contemporary plantation labor regimes, which have pivoted between freedom and unfreedom more than once. Stated abstractly, workers want to be free, but they want employers to be constrained; employers want to be free, but they want workers to be constrained. For workers, the ideal labor regime is one that preserves their freedom to seek the best price for their labor power while obliging employers to take shared responsibility for social reproduction (maintaining workers and the families, communities, and other social, political and economic institutions that support and replace workers across time). For employers, the goal is to secure well-disciplined labor at the lowest possible price. Employers may achieve this goal through market means, if labor power is abundant and workers unprotected. Or, they may achieve the same goal through unfreedom, by locking in labor power at below-market price and preventing worker mobility. Seen in this way, unfree labor is not an archaic holdover from the past. New forms of unfreedom may emerge when they serve employers' interests. ${ }^{9}$ Rather than proceed in a historical sequence from unfree to free, the trajectory may be the reverse: employers impose unfreedom when they find workers to be too free, that is, too capable of rejecting their conditions of work. Conversely, employers may switch from unfree to free labor relations not from benevolent concern, but in order to increase their profit. ${ }^{10}$

Concretely, practices that make labor free or unfree emerge from struggles between workers and employers in the context of particular labor regimes. I use the term labor regime to refer to the assemblage of elements that set the conditions under which people work. Each labor regime is unique, yet formed from common elements that furnish grounds for comparative analysis. Key elements of plantation labor regimes include the material requirements of different crops and their associated technologies; employer practices for labor sourcing and selection (often spatialized, racialized, gendered, and ageist); schemes for reward and punishment; and economic and political contexts that empower workers or employers in specific ways. Of particular relevance is the degree to which workers can access land to grow food and/or to grow the plantation crop independently; worker capacities to assert legal rights and/or de facto individual and collective powers to advance their interests; and the allocation of responsibility for social reproduction between workers, employers, and other agencies, a matter often overseen by states and inscribed in law.

In contemporary Indonesia, the political and economic contexts strongly favor employers. The country's 2003 Labour Law protects only permanent

${ }^{9}$ LeBaron (2015) examines new regimes of labor bonding formed within contemporary capitalism.

${ }^{10}$ Brass 2010: 30-31. 
workers, who are a diminishing portion of the total plantation labor force. ${ }^{11}$ The juridical absolution of employers from responsibility for social reproduction is in step with an economic context in which severe unemployment and underemployment on the labor-stuffed island of Java and in other parts of the archipelago present plantations with an unending, disposable labor supply. Although there are instances of workers being held against their will, the trend is toward a dangerously free labor regime in which employers and workers are linked only by a transitory cash nexus. Would-be plantation workers must compete for jobs, and behave as entrepreneurs as they seek individual pathways for survival and advance. Employers are free to buy units of labor power as needed, selecting for the particular (gendered, spatialized, racialized, age-related) capacities required for a particular task. They make no commitments to workers, and seek none in return.

The extensive use of casual and contract labor on Indonesia's contemporary oil palm plantations sets them apart from the colonial period, when unfree labor was common. The present regime is also distinct from that on state-owned plantations in the New Order period (1966-1998), when full-time workers enjoyed significant labor rights and were subject to the extensive, if paternalistic, care of a near-total institution. Finally, it is distinct from the contemporary labor regime on oil palm plantations in Malaysia, in which migrant workers $(90$ percent of them Indonesian), make up 70 percent of the plantation workforce. In return for the right to work in Malaysia, migrant workers must sign two-year contracts that bind them to a single employer. They sign up because the pay is significantly higher than they could earn at home, even after they pay off debts for their passage. Their work permits forbid them from bringing their families. If they abscond from the plantations to which they are assigned, or overstay their visas, they are in breach of immigration rules and vulnerable to harsh penalties including caning and imprisonment. ${ }^{12}$ Echoing colonial indenture, plantation owners in collaboration with the Malaysian government have instituted an unfree labor system because it enables them to discipline workers and also to immobilize them, thereby increasing profit. More specifically, it prevents workers from seeking better pay on a neighboring plantation, or in another sector of the economy such as construction where the wages are higher. Most workers going to Malaysia know what to expect. They are nevertheless unfree, in the sense that their right to sell their own labor power is suspended for the duration of the contract and they have no legal way to escape abusive work situations. $^{13}$

11 Tjandraningsih 2012; International Labor Organization 2013; World Bank 2010; Siagian et al. 2011; Sinaga 2013; Sirait 2009; Institute for Ecosoc Rights 2014.

12 Robertson 2008; Kaur 2014; Accenture 2012; Amnesty International 2010; Ramasamy 1992; Pye et al. 2012; Pye 2015.

13 Following Brass (2010: 26), my definition does not hinge on whether the employment relation was entered voluntary, but rather on the outcome: unfree workers are prevented from selling their 
Malaysia's contemporary unfree oil palm plantation labor regime is outside the scope of my comparative inquiry in this essay. As I noted, the problem faced by plantation workers in Indonesia today is the opposite one: an excess of (market) freedom, which turns out to be quite terrifying as well. My study focuses on Indonesia, and compares plantation labor regimes in the colonial, New Order, and "reform" periods (post-1998) to answer three questions. First, given that employers always want to access suitably skilled, disciplined labor at the lowest possible price, what were the conditions that led employers to rely on unfree labor in some cases, and "free" labor in others? Second, to what extent was unfreedom imposed as a response to excessive freedom among workers and peasants? Third, how were the costs of social reproduction distributed between workers and employers, and what pressures from workers or regulators (state, colonial, transnational) affected this distribution? I begin with the colonial period, where employer concerns about excessively free labor played a surprisingly important role.

\section{INDONESIA'S COLONIAL PLANTATION LABOR REGIMES}

Colonial plantations in the Netherlands East Indies depended primarily on unfree labor. There are two common explanations for this practice. One is that colonial powers were absolute. They were not balanced by liberal notions of rights, and workers were subject to coercive extraction without restraint. ${ }^{14}$ A second explanation, favored by colonial authorities, was that native populations were primarily peasants, satisfied with their subsistence ways, who had to be coerced into laboring on colonial export crops. Only coercion could remove "lazy natives" from their indolent condition and teach them the value of diligent effort. ${ }^{15}$ Shorn of its patronizing language, there was a truth to this idea in that native populations in control of their own means of production refused to do plantation work.

A third explanation, proposed by Bernstein, Brass, and others in an important comparative volume on Asia's colonial plantations, begins from the observation that a great many of the workers deployed to produce colonial export crops were already landless circa $1800 .{ }^{16}$ Hence "the object of unfree agrarian relations was not to force a long-standing or newly reconstituted peasantry to become workers ... so much as to stop precisely such a transition from

own labor power at market price. Definitions that hinge on consent occlude the fact that most people are compelled to sell their labor. These definitions also concede too much ground to colonial indenture and contemporary foreign worker programs that justify the suspension of market freedom (and other labor rights) on the grounds that workers enter their contracts voluntarily (McKeown 2012: 43-44).

14 Mbembe 2001.

15 Alatas 1977; Breman 2015.

16 Daniel, Bernstein, and Brass 1992. 
taking place: that is, to prevent/preclude a de facto proletariat from becoming, continuing or acting as such." 17 This third explanation offers novel insights on the use of unfree labor in the two colonial plantations systems I explore here: one on the island of Java dedicated to the production of coffee, the other on Sumatra where the crops were tobacco and rubber.

\section{Coffee versus Tea: Unfree Labor in Java, 1725-1917}

For almost two centuries, coffee was the most significant tropical commodity produced in colonial Java. As Jan Breman has shown, a particularly vicious regime of unfree labor in the Priangan highlands of western Java was at its core. ${ }^{18}$ The scale was enormous. Priangan coffee was a key source of revenue for the Dutch East Indies Company (VOC) and for the successor colonial regime. In 1823, coerced coffee mainly from the Priangan provided 77 percent of Netherlands East Indies' export revenue. ${ }^{19}$ Circa 1840,65 percent of all landholding households in the Priangan and more than 30 percent of all households in Java were forced to grow coffee (four times as many people as were forced to grow sugar); coffee furnished over 80 percent of colonial profits. ${ }^{20}$ The government abolished forced sugar production in 1870 , but coffee in that year still provided a third of public revenue. ${ }^{21}$ To meet coffee quotas, landholders sourced additional workers from among the 30 percent of the native population that was already landless. Some members of this protoproletarian class roamed freely in search of work, while others were attached to landholders as tenants or farm servants, or bound to local chiefs through debt and corvée obligations. ${ }^{22}$ Rather than engage with landless workers as such, the Dutch classified "free," unattached workers as criminals and vagabonds, and sought to reinforce the bonds that tied them into households and communities, all in the name of preserving native tradition. ${ }^{23}$

Idioms of tradition served multiple purposes. Colonial authorities absolved themselves of responsibility for social reproduction by arguing that "lazy" native landholders had untapped reserves of land and labor, and could be obliged to grow coffee without unduly disrupting village life and food production. They made native chiefs responsible for ensuring forced coffee deliveries, which reduced the costs of supervision and enabled the Dutch to frame these deliveries as a continuation of existing tribute obligations. Landholders, in turn, deepened their hold over unfree workers lodged within their households

17 Brass and Bernstein 1992: 17.

18 Breman 2015. See also the review essay I coauthored (Li, Pelletier, and Sangadji 2016).

19 Kano 2008: 35.

20 Clarence-Smith 1994: 241; Fernando 2003: 171; Elson 1994: 99, 304.

21 Clarence-Smith 1994: 245.

22 Boomgaard 2009; Knight 1988; Breman 1983.

23 Schrauwers 2001. 
and passed on to them the burden of producing food and/or coffee in ever increasing amounts.

Landholders first met their quotas by planting coffee close to their homes and fields, but as the available land ran out, they were obliged to plant coffee in distant "gardens" that were more like industrial-style plantations with up to two hundred thousand coffee bushes in mono-cropped blocks. Colonial authorities forced thousands of unpaid workers from different villages to work in these "gardens" without organizing a supply of food, since they assumed that the households to which the workers were attached would somehow provide for them. ${ }^{24}$ Yet distance from village settlements (up to eight hours walk) and the imposition of labor service on women and children undermined food production, and field supervisors intent on an orderly appearance forbade workers from planting food among the neat rows of coffee. ${ }^{25}$ Payment for the coffee beans was very low, and received only after they were delivered to distant warehouses. Even that was uncertain since the gardens were poorly sited, and some yielded nothing at all.

The combination of agronomic failure and the inability of workers to sustain themselves under these conditions turned the "gardens" into a disaster. By the 1860s, ever more intense pressure to mobilize both land and labor in the Priangan resulted in the production of less and less coffee. No amount of violence applied against workers or landholders (caning, lashing, placing in stocks) could restore production to its former peak. ${ }^{26}$ The freedom of the colonial power to do as it wished, unconstrained by responsibility for the social reproduction of the subject population, had pushed the system of forced coffee cultivation to the point of ecological and social collapse. No doubt worker refusal played a part in the collapse, but it was barely reported in the colonial archive, where the "myth of the lazy native" went unrevised.

Breman's main explanation for the severe form of unfreedom installed in the Priangan is the very high rate of extraction it enabled. Vagrancy laws bound workers into households where they could not sell their labor freely or bargain up the price, and prevented both workers and landholders from absconding to set up independent farms on the forest frontier. The coerced coffee system was also designed to curtail the freedom of landholders to grow this lucrative crop on their own account. Priangan highlanders started planting coffee soon after seedlings became available (around 1700), but in 1723 the VOC imposed a monopoly banning free trade in coffee. Three years later, with its coercive apparatus in place, the VOC reduced the price it paid to independent coffee producers by 75 percent, and then dropped it again by doubling the standard

\footnotetext{
24 Breman 2015: 189, 169-73; Clarence-Smith 1994: 253.

25 Breman 2015: 169-72, 272-73, 352.

26 Ibid.: 245, 252, 306, 362-63.
} 
weight. $^{27}$ Producers responded by destroying their coffee plants, and the regime of coerced coffee commenced. Unfreedom was marked by relabeling transactions in non-market terms. Landholders handing over their forced deliveries were not paid a price but merely a "collection allowance," and the transfer was not described as a sale, but as payment of tribute or rent for land and coffee trees which the colonial power claimed to own. ${ }^{28}$

In other parts of Java, the Cultivation System of forced production that ran from 1830 to 1870 was less extreme: the coffee "allowance" was three times higher than that paid in the Priangan, and landholders were permitted to continue independent production, which they did with enthusiasm. In 1867, in response to surging market prices, independent coffee farmers in the Pasuruan area of eastern Java hired around ten thousand "free" workers and paid them competitive wages. ${ }^{29}$ It turned out that "lazy natives" were both industrious and entrepreneurial when free to work on their own terms. The purpose of unfreedom, in sum, was not to engage peasants or workers in coffee production, but to prevent them from growing coffee or selling labor freely and thereby sustain coercive extraction and monopoly profit.

In the Priangan, the new plantation regime that emerged after the collapse of coffee presented the problem of freedom again, in a new form. Responding to provisions in the 1870 Agrarian Law that encouraged outside investment, Dutch and other foreigners expanded private tea plantations from an area of 2,400 hectares in 1870 to 220,000 in $1926 .^{30}$ To prevent competition, local landholders were forbidden to grow tea. The plantations recruited landless workers from surrounding villages, a class that had expanded due to polarization among landholders and reduced demand for attached farm servants following the end of coerced coffee. ${ }^{31}$ Faced with an ample labor supply, planters hired workers on a causal basis and took no responsibility for their social reproduction. Yet planters who profited from their landless workers "freedom" soon found that their workers were too free. As one colonial estate manager observed, "In the Priangan Regencies you will often hear not a single complaint about anything, not even a murmur, and then the permanent employees of an enterprise will suddenly up and leave, and not a few at a time; in other words, all of the day-laborers will simply not turn up for work. If you then instigate an inquiry, they will say that something came up...."32

The colonial archive does not reveal how tea plantation workers achieved sufficient autonomy to exercise this bold and implicitly collective kind of

27 Ibid.: $58-65,77$.

28 Ibid.: 66-67, 72, 107, 115. Schrauwers $(2011$; 2001) explores the displacement of market logics by administrative logics in the Cultivation System.

29 Breman 2015: 271; Clarence-Smith 1994: 248, 252-55, 259-60.

30 Breman 2015: 337.

31 Ibid.: $315-16,342$.

32 Ibid.: 343. 
freedom. Did they have savings from wages, access to small plots of land, or family and community support? Were they confident that they could find other work? Planters frustrated by their lack of control responded by obliging workers to sign employment contracts but enforcement was difficult. Harsh contracts backed by penal sanctions were central to the form of unfreedom that was imposed on migrant workers recruited by tobacco and rubber plantations in colonial Sumatra, to which I now turn.

\section{Tobacco and Rubber: Indenture and Wage Work in Sumatra, 1860-1965}

Sumatra's colonial plantations began to be established around 1860, and by the time of Japan's invasion in 1942 they covered one million hectares. ${ }^{33}$ Tobacco dominated until rubber was established around 1910; oil palm was first introduced around 1910 and established as a plantation crop by the 1930s, expanding heavily after 1965 on new plantations and as a replacement for rubber. ${ }^{34}$ Sumatrans were unwilling to become plantation workers so long as they retained access to their own land, hence the main workforce for the first halfcentury comprised indentured male workers recruited from China and Java on three-year contracts. In 1902 these "contract coolies," as they were called, numbered about ninety-four thousand, supplemented by around four thousand "free" casual workers (4 percent of the total plantation workforce). ${ }^{35}$

Dutch authorities insisted that indentured workers had signed their contracts "freely" and could therefore be forced to abide by them. Workers were free to enter, but not to exit. ${ }^{36}$ Under the terms of the Coolie Ordinance first imposed in 1880 (phased out after 1911), contract infractions such as failing to show respect, weak effort, attempted desertion, and insurrection exposed workers to penal sanctions including flogging, imprisonment, and death by hanging. Tobacco cultivation and processing was detailed work and closely supervised. Workloads were extremely demanding, and food, health, and hygiene conditions were poor, which led to high rates of mortality. Colonial officials were aware that rates of pay were below the minimum necessary for subsistence, but failed to intervene. ${ }^{37}$ Subsistence was, at best, strictly individual: with the possible exception of those who became foremen, workers were unable to save money to remit to their families, and many took on further debt. $^{38}$ Plantations were locked down at night to prevent flight, leaving opium addiction and suicide as the only ways out of a dire situation. ${ }^{39}$ Exploiting, starving, or punishing workers so severely that they died on site, or

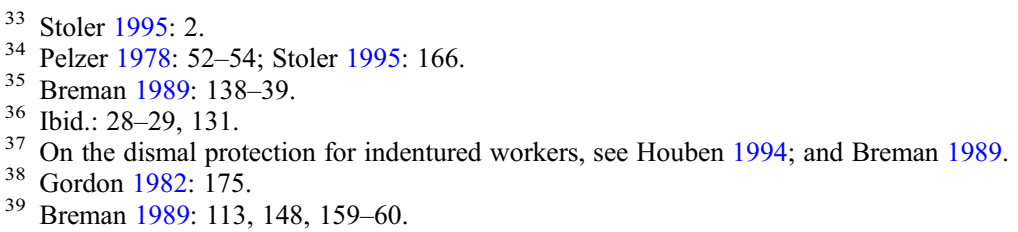


returned to their place of origin used up, like "sucked oranges," was profitable so long as recruitment costs were low. ${ }^{40}$ Replacement had the added advantage that new recruits were in better health, at least on arrival, and they were more easily disciplined than old hands, who had devised covert strategies for individual or collective resistance. ${ }^{41}$

As in the Priangan, it is easy to read this vicious form of unfreedom as the product of unrestrained colonial power, and overlook the role of freedom in its formation. The majority of the migrant "coolie" workforce recruited from India, China, and Java to work on colonial plantations in Sumatra and Malaya were "free" of ties to land, that is, landless in their places of origin. They were also free of bondage: kuli in the Tamil language is the type of payment received by an unattached worker without customary rights or duties, in contrast to pannaiyal, the type of payment received by a bonded or unfree worker. $^{42}$ Coolie became the generic word for migrant workers who were recruited from marketplaces, roads, and docks, where they were both socially and economically adrift. ${ }^{43}$ It was this kind of freedom that made them open to indenture: they were desperate for work, and they could mortgage their own labor power in return for an advance on wages and the hope that they could improve their situation.

From the planters' perspective, the hope that induced workers to depart overseas helped to mobilize them, but it was also a risk, since workers might try to abscond on arrival to seek better paid work on neighboring plantations, or establish themselves as independent producers. It was this "excess" of worker freedom that Sumatra's indenture contracts were designed to curtail. Similar contracts were used to immobilize migrant Chinese and Tamil workers in colonial Malaya, and they were used within India to immobilize migrant workers on Assam's extensive tea estates. ${ }^{44}$ Distance mattered: in French colonial Vietnam, migrant workers were recruited from afar, but they were still within the colonial territory and found ways to return home. They deserted in such huge numbers that rubber planters in the 1920s had to recruit seventy-five thousand workers in order to maintain a workforce of twenty-two thousand. To impress upon these workers that the contracts they had signed made them unfree, recruiters subjected them to indignities such as escort under armed guard, medical checks, and confinement to military- or prison-style barracks complete with barbed wire. ${ }^{45}$ In Sumatra, ex-plantation workers who managed to stay in the plantation area after desertion or the

\footnotetext{
40 "Sucked oranges" was the label for indentured Indian plantation workers in Malaya (Institut Analisa Sosial 1989).

41 Breman 1989: 169.

42 Breman and Daniel 1992: 269.

43 Brass and Bernstein 1992: 19; Breman and Daniel 1992: 274-76.

44 Ramasamy 1992: 93; Breman 1989: 37; Kaur 2014; Behal 2014.

45 Murray 1992: 57, 51-53.
} 
expiry of their contracts joined the "free" labor force, took up tenancies, or engaged in independent production. ${ }^{46}$ Chinese ex-coolies were expressly forbidden from accessing land for fear they would hire workers and out-compete plantations. ${ }^{47}$ For the same reasons, tobacco was a plantation monopoly: local landholders were forbidden from growing it and all tobacco leaves had to be shipped to the Netherlands. ${ }^{48}$

Formal indenture was phased out after 1910, although the labor contracts that replaced indenture were only slightly less coercive. ${ }^{49}$ In the 1920 s, however, planters shifted away from unfree labor systems, for three main reasons. The first was a change in the crop, since rubber, which replaced tobacco, needs far less labor (only one worker per hectare, compared with tobacco's five). Rubber work is also less detailed and needs less supervision, and strikes and labor disruptions are less serious than for tobacco, which rots if it is not harvested and dried on schedule. ${ }^{50}$ Second, although the colonial regulatory regime strongly favored planters it did commit them to paying contracted workers a stipulated wage. When the price of rubber collapsed in the 1920s due to overproduction, planters hastened to send back their contracted workers to save on costs. Third, planters changed their concept of the ideal worker as Chinese and Javanese workers, stirred by nationalist and communist ideas, began to mobilize collectively. ${ }^{51}$ Planters refused to read protest action in class terms, and reframed it as the isolated action of criminal individuals. They were particularly alarmed by the conduct of single young Javanese men, who they previously viewed as childlike and obedient and now characterized as prone to "irrational" outbursts of extreme violence. ${ }^{52}$ Planters replaced unmarried with married men, who they assumed would be more docile, but they balked at the high costs of social reproduction that the presence of families obliged them to absorb. They engaged in inconclusive debates about the merits of forming labor colonies outside the plantation, or assigning couples small food plots within it, strategies that would reduce the wage bill but risked making workers too autonomous, impeding labor discipline. ${ }^{53}$

The collapse of rubber prices in the 1930s depression gave planters a further excuse to fire surplus workers. Neither planters nor government authorities took responsibility for the welfare of the hundred thousand workers they sent back to Java at the height of the depression. They were content to assume that the workers' families and communities could provide for them, although

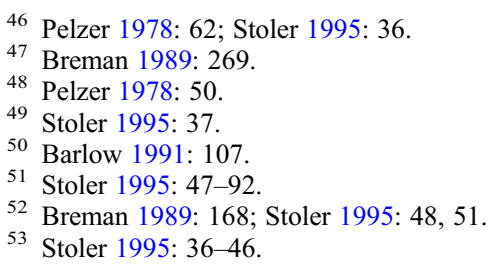


the reality was much less accommodating. Destitute ex-workers set up makeshift camps, and authorities soon began to label them as criminal and dangerous. ${ }^{54}$ Among those who remained in Sumatra as "free" workers, some were re-hired by plantations at 25 percent of their former wage. ${ }^{55}$ Workers clearly paid a high price for their "freedom," in the context of market collapse, but they also embraced their increased autonomy by taking over unused land inside or around the plantations to farm and building squatter settlements.

Planters opposed the squatting movement, which caused a labor shortage on plantations, but over the long term workers' attempts to ensure social reproduction on their own terms presented planters with a valuable opportunity. After a generation the squatters ran out of land, making them an ideal source of cheap, casual labor power for planters to hire at will. ${ }^{56}$ During the depression years and the Japanese occupation, the collapse of plantation wages made independent food production a matter of urgent survival. The squatting movement was supported by the Indonesian Peasant Front and plantation workers' unions, though with ambivalence: worker unions recognized that their members aspired to a future as independent farmers who would be free from plantation control, but squatters had one foot inside and the other outside the plantation, which undermined worker solidarity and union strength. ${ }^{57}$ Former plantation workers also competed for land with the local population, resulting in tensions and clashes. ${ }^{58}$

Plantation unions grew in strength in the 1950s. They achieved gains in worker pay and conditions and successfully opposed planter efforts to further "casualize" the workforce. Unions pushed to expand planter responsibilities for social reproduction, and secured more individual and family-based rights for both permanent and casual workers. ${ }^{59}$ The nationalization of foreign-owned plantations in 1957 curbed the unions and strengthened the role of the military, which Sukarno tasked with ensuring the orderly takeover of estates and maintaining export revenue. ${ }^{60}$ Military control led to the eviction of squatters and the marginalization of unions, and culminated in the 1965 massacre of half a million people, among whom were a great many peasants and plantation workers. ${ }^{61}$ General Suharto founded the New Order government upon this

54 White 2015: 9-11.

55 Ibid.: 6; Stoler 1995: 43-44.

56 Stoler 1995: 37-38, 157, 215 n23.

57 Ibid.: 125-61. The plantation worker union SARBUBRI was reported to have a million members in 1947, making it by far the largest component in SOBSI, the federation of labor unions which claimed to have 1.2 million members overall (ibid.: 121).

58 Pelzer 1982: 134.

59 Stoler 1995: 137-39.

60 Ibid.: 148; Pelzer 1982: 163.

61 Stoler 1995: 163. The Indonesia Peasant Front had 8.5 million members before its annihilation in 1965 (Pelzer 1982: 45). For a discussion of the work of the peasant and plantation workers' unions and the fate of their members in 1965, see White 2016. 
"mountain of skeletons," 62 a violent beginning that continues to haunt Sumatra's plantations, as Joshua Oppenheimer's film The Look of Silence (2014) powerfully confirms.

STATE OIL PALM PLANTATIONS AND THEIR TRANSFORMATION, 19652015

North Sumatra, 1965-1980

Under New Order rule, Sumatra's nationalized plantations were run in a military-corporate-bureaucratic style. New Order ideology denied the discrete interests of labor and capital, preferring the model of an enterprise as a family. ${ }^{63}$ In the state plantation sector, this approach meant blending authoritarian paternalism with significant labor rights, since permanent workers in state enterprises held a status similar to that of civil servants. It also meant corruption and collusion, in which workers at all levels of the plantation hierarchy had a stake. ${ }^{64}$ Plantation jobs were good jobs if you could get them, but between 1965 and 1978 Sumatra's state and private plantations reduced their permanent workforce by more than half (from 282,804 to 119,738 ). ${ }^{65}$ The planters' preferred worker was once again the single young man. Managers were reluctant to hire women as permanent workers because statutory entitlements to menstrual and maternity leave made them unduly expensive. By reducing the number of married men with dependents, planters rid themselves of responsibility for 130,000 children previously eligible for rice subsidies. ${ }^{66}$

By the time of Ann Stoler's research in Sumatra's plantation belt in the late 1970s, state plantations had a small core workforce and some private plantations had no permanent workers at all. The progressive displacement of rubber by oil palm enabled this shift: palms need only one worker per 3-10 hectares. ${ }^{67}$ The presence of squatter settlements tucked around the rubber and oil palm plantations was another factor, since managers had no trouble finding casual workers.

State plantations could cast off used up and useless workers if they were casually employed, but the rules governing state enterprises obliged them to sustain their permanent workers even as they aged. In Sumatra, state plantations minimized their exposure by reducing the size of their permanent work force. But as these plantations expanded onto new land frontiers where no labor

62 Anderson 1999: 7.

63 Ford 1999: 376.

64 Stoler 1995: 172-78. Aspinall and van Klinken (2011) describe routine illegality in New Order and post-New Order state agencies.

65 Stoler 1995: 166.

66 Ibid.: 4, 166-71, 225 n9.

67 Cramb and McCarthy 2016a: 66 n9; Stoler 1995: 166-69. 
reserve was in place, they had to absorb a full set of responsibilities toward their permanent workers, a story I turn to next.

\section{West Kalimantan, 1980-2003}

Under the New Order, state plantations had the dual mandate of generating export revenues and bringing about "development" by transforming Indonesia's underpopulated and underutilized frontiers into sites of order and productivity. ${ }^{68}$ Their expansion into West Kalimantan circa 1980 was led by Sumatran, specifically Batak plantation managers who had learned their technical skills on Sumatra's plantations and in training schools. They had also absorbed some colonial ways of thinking, and they fully expected Kalimantan's native Malay and Dayak population to be lazy and unreliable. ${ }^{69}$ Indeed, like the native population of Sumatra a century before, Kalimantan natives were initially uninterested in becoming "coolies" on plantations because they had ample land. Their situation changed as the land frontier closed and their homeland became saturated with plantations. This was the case for the Dayak and Malay people living in tiny enclaves in and around the state plantation I studied in 2010-2015, which I call PTPN-ME. ${ }^{70}$ They were virtually landless, but could find at best only casual work.

In 2010, PTPN-ME covered 5,640 hectares, and had a permanent workforce of 883 (one worker per 6 hectares). ${ }^{71}$ Almost all the field workers had been imported directly from Java through a program organized by the Department of Labour. As one woman worker recalled: "Our village headman in Gunung Kidul called us to a meeting and asked if we wanted to go and we said yes, yes, yes. Lots of people wanted to go. In Java we were just getting by (hidup pas-pasan). There are too many people and not enough work." In keeping with New Order ideology, which stressed the family as the building block of the nation, workers were recruited as married couples and provided with the means to lead a decent family life: housing, child care, monthly transport to town to buy provisions, and a rice ration for up to three children. ${ }^{72}$ Since there was no proximate labor reserve, the pro-family state ideology coincided with the plantation's need to import and hold migrant workers. PTPN-ME hired both husbands and wives as permanent state employees. Men and women undertook gender-segregated tasks (men in harvesting, women in palm

${ }^{68}$ Dove 2011: 24-25.

${ }^{69}$ Dove 1999.

70 My primary research in this location and at an adjacent private plantation I call HD-DS was conducted together with Dr Pujo Semedi of Gadjah Mada University, and students from Gadjah Mada and the University of Toronto.

${ }^{71}$ PTPN-ME official data show that 713 were fieldworkers, and 170 were office, technical, and supervisory workers, and 34 percent were women. The research team estimated that 70 percent were Javanese, 8 percent Batak, 12 percent Dayak, and 7 percent Malay.

72 Elmhirst 2011: 175. 
maintenance), but under the same pay structure and with the same set of benefits, including pensions. Workers who arrived in 1980 recalled that the pay was low, but so was the cost of living. They were able to begin saving right away.

To a remarkable degree, the plantation operated as a near-total institution that took responsibility for the daily and intergenerational social reproduction of its workers. Workers I interviewed often mentioned the medical attention they received in the plantation clinic or PTPN hospital, and subsidized education for their children if they entered state universities. They also mentioned the dignity afforded by their living conditions and formal worker status. They were no longer coolies, a term they reserved for pitiful people who could be kicked around, but rather karyawan, employees. ${ }^{73}$ They were subject to a bureaucratic regime that was hierarchical and paternalistic, but which offered them security and a significant set of rights. In return, they were prepared to keep their compounds tidy and plant flowers to model good order and development. They had no functioning union and did not strike. They were free to leave, but the plantation could not fire them at will, and was bound to support them even after retirement. Their experience over the period 1980-2003 confirmed the New Order premise that state plantations could deliver benefits to workers and to the nation, within a technocratic framework. All was quiet until 2003, when the labor regime began to shift.

\section{Transformation of the State Plantation Labor Regime, 2003-2015}

After 2003, PTPN-ME no longer provided for the social reproduction of workers within the confines of the plantation. That was the last year it recruited married couples, or fieldworkers of either sex, as permanent employees to replace the aging workforce. Neither the workers' own children nor other aspirant workers could obtain permanent jobs. The rationale for the shift was cost-cutting and efficiency. Like other state and para-statal corporations in this pro-business, "neoliberal" period, state plantations had been given a new mandate: their task was no longer to support national development and poverty reduction, but rather to match or exceed the private sector in productivity, and make a profit.

A new Labour Law passed in 2003 under pressure from the IMF helped managers shift the labor regime. The law strengthened the rights of permanent workers while weakening the position of contract and casual workers, most of whom did not qualify for legal protection. PTPN-ME's capacity to take advantage of the legal shift was enhanced by the emergence of a proximate labor

\footnotetext{
73 See Kompas 1997, for an account of the scorn heaped on "koeli kontrak." Stoler (1995: xxvii) notes that Indonesian censors wanted to rename her book "from kuli to karyawan," a title she found too celebratory. The pro-planter union SOKSI introduced the term karyawan to obliterate "the necessity for class struggle" (ibid.: 159).
} 
reserve squeezed into tiny enclaves around its borders, as the proliferation of plantations had left the former Malay and Dayak landholders with insufficient land to farm. A wider provincial labor reserve had formed as well. By 2003, PTPN-ME's managers could recruit their preferred workers-landless, young, male, and Javanese - from within Kalimantan. Some were sons of plantation workers, while others were sons of transmigrants who had been allocated farmland in state-sponsored schemes that relocate families from crowded islands (mainly Java and Bali) to less populated areas like Kalimantan. Since the program grants each family just 2 hectares, it routinely generates landlessness among the second generation and swells the pool of people needing to find paid work. $^{74}$

After 2003, PTPN-ME managers only took responsibility for their small residual core of aging permanent workers. They could approach other workers as mere vendors of the commodity "labor power," and specify the bodily and mental characteristics required to match "labor power" to particular plantation tasks. The result was intensified segregation by gender, age, ethnicity, and migrant status. Managers were especially concerned about efficient harvesting, a skilled task that must be carried out on a bi-weekly basis. If harvesting is late, the palm fruit bunches rot, but if harvesting is early, the fruit is immature. When the palms are very tall (after fifteen years) harvesting requires attaching two or three poles to the curved harvesting knife to reach the fruit. Injury is common, and PTPN-ME's aging permanent workers could no longer do the job. Hence managers sought a particular type of harvest worker: healthy, skilled, young men who were dedicated to plantation work, and also docile and diligent-ideally, Javanese.

Two systems emerged to supply the right type of harvest workers. One involved informal subcontracting by permanent workers, who recruited young men from Java claiming they were nephews who had come to visit and were just helping out; the workers and their colluding supervisors appropriated a percentage of the "nephew's" pay. The second, more formal solution devised by PTPN-ME's managers was to recruit young male Javanese workers already in Kalimantan on limited two-year-term contracts (PKWT, perjanjian kerja waktu tertentu). These contracts carried no pension provisions. If the young men were accompanied by wives and children, PTPN-ME did not provide family members with health care, nor offer the women steady employment. The workers resented their reduced status. "They just want to use us then throw us out" was a common refrain. Although the pro-family principles of the state ideology had not changed, in practice daily and intergenerational reproduction had become a problem that young male workers and their families had to solve for themselves.

${ }^{74}$ I examine the role of transmigration in plantation labor supply in Li 2016. 
The older permanent workers were also faced with new rules, as managers insisted that they vacate their houses on retirement. ${ }^{75}$ In the past, retiring workers were often able to stay on in their plantation homes through informal agreements, or because their children obtained permanent plantation jobs. Now older workers had to seek extra income to buy land and build a house for their old age. They stepped up their entrepreneurial activities both within and outside the plantation (e.g., starting food stalls, grazing cattle among the palms, generator repair), and the graft, theft, and other illegal activities that are routine elements of plantation life. Stealing time was a common practice I observed in 2010 at PTPN-ME, where workers and managers were generally back home by 10:00 a.m. No institution is quite total, as Erving Goffman observed. In addition to the formal rules, it depends on informal accommodations, "the underlife of the institution, being to a social establishment what an underworld is to a city." 76 Workers argued that "unofficial" earnings were necessary to solve the problem of low pay and to save for retirement. They ridiculed workmates who expected the plantation system to provide everything for them as it had in the past.

In addition to 150 young male harvest workers on limited-term contracts, PTPN-ME increased its employment of casual and subcontracted workers whose names did not appear on the official payroll. Wives of plantation workers and landless Malay and Dayak women recruited from surrounding villages maintained the palms. Most of them worked on a casual day labor basis without benefits, and with a rate of pay below the minimum wage. Managers justified the low pay in terms of the short workday (five hours, from 7-12). Building and road construction, and replanting aging palms, were tasks carried out by groups of subcontracted workers of diverse ethnicity. Some were recruited by contractors directly from Java, some from Kalimantan's cities and transmigration zones, and others from villages nearby. Some lived in tents erected near their construction site and others in empty plantation houses, but they were not official residents. They did not bring their families. They lived from contract to contract, attempting to minimize costs, save money, and avoid injury. Like plantation managers, these workers made finely tuned calculations, evaluating the wage they could earn for a particular task in relation to the physical demands it placed on them. For example, young men in good health could make three times the minimum wage doing the strenuous work of land preparation for replanting. They were paid per terrace, and they could dig five to ten terraces per day, depending on the field conditions. Yet the risk of injury and exhaustion forced them to pace themselves. They noted that if they worked too hard on one day, they were sometimes too sore

75 Barral 2014.

76 Goffman 1961: 199. 
and feverish to work the next. The company took no responsibility for their medical expenses if they were sick or injured.

A revisit in 2015 enabled me to glimpse the price that PTPN-ME paid for exercising its legally inscribed freedom to hire and fire at will: the plantation was heavily overgrown and barely produced any oil. A manager explained to me that PTPN-ME was unable to recruit a sufficient number of casual maintenance workers because its daily rate was below that paid by private plantations nearby. He defended PTPN-ME's low pay on the grounds that the standards of housing, health care, and pensions it provided were far higher than those offered by private plantations. His point was that workers looking for quick money did not sufficiently value benevolent (and costly) company care. He neglected to mention that very few workers at PTPN-ME actually enjoyed these benefits because they were not extended to casual and contract workers. Nor did he allude to the corruption that had fueled PTPN-ME's decline.

Faced with a collapse of funds and labor supply, PTPN-ME called on company managers and office staff to break the hierarchy and join manual workers for three days each week to help clear the dense undergrowth from around the palms. Not surprisingly, the office workers lacked the requisite skills, and the result was an embarrassing fiasco. "Real" workers watched the struggling managers' efforts with amusement. The state plantation system was a creature of the New Order's selective paternalism, and by 2015 the labor regime that protected permanent workers was moribund, if not quite dead. The casual labor regime that replaced it was structurally similar to that on private plantations, but PTPN-ME could not compete with private plantations to buy the stripped-down commodity "labor power" at the going market price.

WORK ON A PRIVATE OIL PALM PLANTATION, 1990-2015

Across the river from PTPN-ME was a private plantation, HD-DS, solely owned by a Jakarta-based entrepreneur, a former timber tycoon who had established several plantations in the province with a combined area of tens of thousands of hectares. This plantation, which was established in 1990, had a smallholder scheme attached to it, but here I focus only on the plantation core, which comprised 3,834 hectares. In 2014, HD-DS had a permanent workforce of 358 workers, one-third of them male harvesters and the rest mainly office staff, supervisors, and guards. As at PTPN-ME, palm maintenance work at HD-DS was done by casual women workers recruited from households of landless Malays and Dayaks living nearby. Managers were again reluctant to hire local Malay and Dayak men, who they described as lazy.

For the skilled, time-sensitive harvest work, managers preferred to hire migrant men, either Javanese or workers from the eastern Indonesian province of Nusa Tenggara Barat (NTB), many of whom had experience working as 
harvesters in Malaysia. These workers arrived at the plantation individually or in groups, sometimes with the assistance of a labor broker. Many had borrowed money from brokers, money lenders, or kin to pay their travel costs to the plantation, a debt they treated as a routine and necessary cost of finding work. ${ }^{77}$ HD-DS agreed to reimburse part of their travel costs when they became permanent workers after a six-month trial period. HD-DS managers insisted on the delay to prevent workers from taking the travel money and obtaining equipment on credit from the company store, then promptly moving off. The plantation was not locked down at night, and managers had no practical way to hold workers against their will. New arrivals made good use of their cell phones to call friends working on other plantations, compare conditions, and check their options. They also compared notes on the reliability of brokers. Their freedom to leave was demonstrated by a group of around twenty workers from Nusa Tenggara Timur (NTT) who were unsatisfied with the deal their broker negotiated for them on arrival, and promptly moved on. Workers who decided to stay at HD-DS did so because, in their assessment, this was the best job available.

Workers' freedom to sell their own, commodified labor did not keep them free from harm. Indeed, it left workers and their families dangerously exposed. In the 1970s, oil palm harvesters in Sumatra told Stoler they expected to be burned out after eight years. They talked of being "eaten up" by the plantation's excessive demands: if pushed too far, it is not only labor power that is consumed, but "the person, that is, his ability to maintain and reproduce himself, is consumed as well." 78 Workers at HD-DS expressed similar fears, which were exaggerated during a period of turbulence from 2010 to 2015 when labor power was subject to deepening commodification, and the management reduced its commitments to worker well-being. Here I convey some of the workers' reflections on their embodied experience of commodified labor, and what it meant to have their bodies "used up" on a plantation; on the proper relation between effort and reward; on the calculation of risk; and on employer responsibilities for social reproduction. The core problem, as workers recognized, was their position as a disposable labor force that could easily be replaced. Yet some were more disposable than others, for specific gendered, racialized, spatialized, and age-related reasons.

\section{Male Harvesters}

Most of the harvesters were permanent workers living in plantation housing. Under the new rules HD-DS introduced in 2011, harvesters no longer received a base pay for meeting their daily target, plus a premium for extra fruit. Instead

\footnotetext{
77 McKeown 2012. Indonesian labor brokers and the role of trust and reliability are discussed in Lindquist 2012.

78 Stoler 1995: 198.
} 
they were paid a flat rate per kilogram. The change enabled HD-DS to reduce the pay of harvesters who failed to meet their targets, often older men. It also devolved all the risk onto the workers. Difficult terrain, dry weather, small or sparse fruit, and days of work lost due to illness or injury translated directly into lost income. Younger harvesters recognized that they could potentially earn more under the new system, but they too rejected the change because it seemed to demote them to casual status and remove them from the protection of the 2003 Labour Law. If they had no basic wage, how would the company calculate the annual pay raise they were supposed to receive, or their annual bonus? Would they still be entitled to pensions? What would happen to them if they were sick or injured? They had many questions about the new system, and saw the company's refusal to clarify as a bad sign.

After a few months harvesters went on strike for three days and demonstrated outside the office complex. The managers made them some verbal promises about paid sick days, but these were not followed through. The harvesters' summary was that the company did not take proper care of them as workers. Some Malay and Dayak harvesters recruited from nearby villages left HD-DS and pieced together income by harvesting for oil palm smallholders and tapping some remaining rubber. Oil palm smallholders paid daily wages higher than the plantation, but the work was less stable. Migrant harvesters had less access to paid work in the smallholder sector since they lacked local networks and had no motorbikes to reach distant plots. They were also tied down by their residence in plantation housing. Hence for migrants the choice was to leave or stay. Fifteen permanent harvesters left on one day, enticed away as a group by another plantation that heard about the turmoil and sent a bus to pick up them up. Most married harvesters, unwilling to move children during the school year, decided to wait to see if conditions would improve. Meanwhile managers took initiatives to fire "lazy" locals, namely Malays and Dayaks, and renewed their efforts to recruit migrants direct from NTB. The result of these actions by managers and workers was turnover: HD-DS records show that of 119 harvesters in place in 2014, two-thirds had been recruited since 2010 .

Incoming migrants from NTB arrived with a calculative mentality already entrenched. They had left their wives and children behind in order to earn money, and they wanted to ensure that their sacrifice was worthwhile. In interviews, they presented themselves as entrepreneurs who had taken the initiative to improve their situation. ${ }^{79}$ For some of them, the goal was to save money to finance a return to Malaysia, while others had a target like sending a child to university. "If we stay in NTB," one observed, "the most we can earn is enough to get by from day to day.... What we are looking for here is the

\footnotetext{
${ }^{79}$ Similarly, Indonesian migrant workers in Malaysia see themselves as "resourceful agents of their own biography" (Pye 2015: 188).
} 
possibility to earn more than we spend, to get ahead." Workers worried about how their families were surviving and about whether their wives would remain faithful to them. NTB has a notoriously high divorce rate and a telling name, jamal, for women left behind. Jamal is a contraction of janda Malaysia (janda means widow or divorcee) ${ }^{80}$ Considering the height of the aging palms, the small size of the fruit, the debts they had incurred for travel, and the cost of the necessary equipment (harvest knife and pole) and basic furnishing for their bare, shared, barrack rooms (a mattress and pillow, a cooking pot), they worried that they would barely make ends meet. It would take months before they could begin to send money home.

By 2014, HD-DS recognized that its per kilogram piece rate had successfully reduced the wage bill, but it was too low to attract and hold skilled harvest workers, which meant fruit was lost. To induce workers to stay it raised their pay, and it also took measures to extract more work from them by entrenching calculation ever deeper in the labor process. The revised payment system combined a quota with "precipice" style, all-or-nothing incentives. A harvester who met his daily kilogram quota every day for twenty-five days a month received a base pay equivalent to the district's official minimum wage. If he exceeded his quota, he received a significant bonus. If he failed to make his quota, or if he missed a day of work for whatever reason (such as a sick child), his pay for the entire month reverted to a low, per kilogram rate. One kilogram below quota on one day, or one workday missed, meant falling off the precipice: "It is as if we just did all that extra work for nothing," one harvester observed, "The company has become really clever."

The new incentive system seemed to give workers a choice: strive to exceed the quota and reap the rewards, or do not and accept the consequences. It induced them to pressure themselves beyond the point of exhaustion in order not to waste their efforts. They came to see the creation of value, and their own potential to appropriate a portion of that value, in every single kilogram of fruit. It was a form of embodiment quite different from the one that workers had experienced under the pre-2011 system, in which discipline took the form of a field supervisor nagging them to work harder. The old system had its faults, as one harvester recalled: "We were supposed to work seven hours, 7:00 a.m.-2:00 p.m., but by 2:00 p.m. we might have only eighty fruit bunches, then a foreman would say, 'Oh, why so little?' and I'd answer 'I was tired today because I worked so hard yesterday, I didn't get home until 3:00 p.m.' I'd become emotional, I was so sweaty and exhausted, so I'd reply, 'What do you know, you just stand there talking?' If we are not careful, it would be so easy to pick up an axe to swing at his head.... There have been cases."

${ }^{80}$ Lindquist 2010. 
In 2015, harvesters who had stayed in place at HD-DS no longer mourned the loss of the old base-pay system, which they recognized had given "lazy" (i.e., local Malay and Dayak) workers too many breaks. They accepted the legitimacy of piece rates, but felt that the "precipice" was oppressive, especially when the palms just did not yield enough fruit to meet the quota. They were prepared to tolerate the pressure so long as the rate was set high enough to enable them to earn well. They saw themselves as smart and calculating, just like the company had become smart and calculating. Company managers knew that harvesters were alert to the market value of their labor power and free to move, factors they took into account when adjusting the pay scale for harvest work. Market competition gave male harvesters some protection from excessive exploitation, but the same conditions left female workers dangerously exposed.

\section{Female Maintenance Workers}

Landless Malay and Dayak women who did the maintenance work at HD-DS sometimes described their casual status positively, as a sign of freedom, but they were only as free as their need for income allowed. They were free to sell their labor, but were trapped and coerced by several factors. One was that they had lost their land to the plantation and so could no longer farm independently. For another, they could not count on a stable income from their husbands since the plantation refused to hire the men and thus obliged them to migrate to seek work elsewhere. Finally, the women's gendered role in social reproduction bound them to their villages where they had to try to anchor families, maintain community, and keep their children in school. ${ }^{81}$ The company was entirely free of responsibility for maintaining these families, and since so many landless women were in need of work it could hire and fire them at will. Managers treated women's work as unskilled, and took into account its non-strategic nature: while a strike among male harvesters led to immediate losses from uncollected, rotten fruit, women's palm maintenance tasks could be delayed. These elements reduced the market price of women's work and enabled the company to impose new rules.

Starting in 2011, women who worked clearing undergrowth around the palms with a bush knife were switched from a day rate to a piece rate, and they lost out heavily. Since much of the plantation was overgrown, they could clear only ten palms per day, giving them an income of one fifth the district minimum wage. Typically, this work was done by older women, whose vulnerability was reflected in the low piece rate for their task. Women who spread fertilizers were switched to a fixed daily rate based on meeting a quota, with no overtime, resulting in a 30 percent reduction in their average

\footnotetext{
81 Landless women working for the plantations on a casual basis while men migrate out is reported in Sirait 2009: 65; Marti 2008: 92-93; and Julia and White 2012: 1004.
} 
monthly income. The work was extremely strenuous. Each fertilizer worker had to spread 350 kilograms per day, 2 kilograms per palm on 175 palms. Their stock was loaded into seven 50 kilogram baskets that were dropped off at the roadside by truck. Women carried the baskets closer to the work site, and then loaded the fertilizer into smaller, 18 kilogram buckets slung from the shoulder, enough for nine palms. The task was especially slow and exhausting on hilly terrain, where they had to climb up and down multiple times to refill their buckets: "Sometimes when I'm carrying that fertilizer I feel I just cannot do it anymore, I'm so worn out.... I get a headache from the smell. It makes my eyes swell up, and I cry until night." As with the harvesters, after 2014 , failure to meet the daily quota meant that the entire month's pay reverted to a low, per kilo rate.

Workers tasked with spraying chemicals were also switched to a fixed daily quota: twelve spray tanks. They were especially vulnerable to injury. In addition to the strain of carrying buckets of water from the river, carrying the tanks on their backs, and continuous pumping action with the right arm, they suffered burns where the chemicals touched their skin. They also experienced damage to their lungs, manifested in a burning sensation, shortness of breath, and chronic coughing. ${ }^{82}$ They did not wear masks, which they said made it impossible to breath. Instead, they tied scarves loosely around their mouths and noses. The effects of the chemicals were severe enough to disable women and stop them from working after fifteen years. The company's response to the health risk was to provide the women with a tin of milk per month - a paltry boost to their strength, and no cure for lung damage. Besides, the supply of milk was erratic. In 2011 the workers had received none for several months. They feared it had been stopped under the new labor system, further evidence of the company's lack of care.

Women workers' attempts to push back against reductions in their pay were limited by their casual status, which robbed them of formal labor rights. The women also lacked a union or any other framework for organizing themselves and linking their struggles to those of the male harvesters from whom they were separated by gender, ethnicity, and migrant status. Hence their attempts at a collective response were small in scale and ineffective. A few of them went on strike for six days to protest against the new rules, but the company threatened to send thugs to intimidate them. A group of women workers inquired at the HD-DS office about short pay: "If they say now we are paid by the day it should really be per day. How can they say it was twenty-two days in December when we worked twenty-seven?" Although they were quite sure the company had stolen from them, they received no response.

\footnotetext{
82 The damage is caused by the chemical paraquat (brand name Gramaxone), which is banned in many countries but still used in Kalimantan (Tenaga Kita and PAN 2002; Julia and White 2012).
} 
Women workers were acutely aware of their disposability and their lack of options. "We have to hold on, where else would we go?" one worker lamented. Forced into plantation work by the lack of alternatives, the best they could do was to attempt to draw a boundary separating the commodity value of their labor from themselves as people. For young women, self-preservation took an expressive form: they rejected the layers of baggy clothing worn by older women to protect their bodies, and came to work in fashionable jeans and T-shirts. They spent their breaks listening to Korean pop music on their cell phones. They acted, in short, as if they properly belonged somewhere else. One seasoned woman worker summed up her approach to retaining her personhood thus: "If we're not smart about it, the company will tire us out." Her friend remarked on the increasingly constrained room to maneuver: "The rules are tighter, wages are tighter. We cannot get ahead, we are really suffering." Another woman focused on balance: tighter rules would be fine, if the pay increased to match. She emphasized the extremely heavy work they had to do, so hard it gave them pain. She was especially alert to the problem of disposability because of her mother's bitter experience. When her mother suffered a workplace injury, a foreman commented callously, "If you're too old to work, you should stop, we only need workers." Although she had worked for the company for decades, her casual status enabled the company to evade responsibility for her medical costs and enduring disability, and her needs in old age. From the company's perspective, she barely existed while she was a workerthe names of casual workers do not appear on HD-DS books. Once she stopped working, she was effectively disposed of.

\section{Regulation's Limits}

Grim as it was, the labor situation at HD-DS was not unusual. Similar labor conditions have been reported on contemporary oil palm plantations across Indonesia. ${ }^{83}$ Most of the practices adopted by HD-DS are legal by default, because casual workers are unprotected by the 2003 Labour Law that was designed to promote labor market "flexibility" and stimulate investment. ${ }^{84}$ Core plantation workers on state and private plantations are among the privileged group of "formal" workers who are protected by the Labour Law, but even for them, enforcement is weak. Only 1 percent of all Indonesian firms are serviced by labor inspectors each year, and remote plantations requiring expensive and time consuming travel are not a priority. ${ }^{85}$ In the absence of reliable state regulation, some workers actually prefer a straight cash nexus. A new

\footnotetext{
83 Wakker 2005: 40; Marti 2008: 79-83; Milieudefensie, Lembaga Gemawan, and KONTAK Rakyat Borneo 2007: 21, 41, 89-90; Sinaga 2013; Situmorang 2010; Institute for Ecosoc Rights 2014).

${ }^{84}$ Tjandraningsih 2012.

85 International Labor Organization 2013: 49. Only 6 percent of Indonesia's total workforce is classified as "formal," and among this privileged group only 20 percent have permanent or
} 
plantation not far from HD-DS opted for a system that made both workers and the employer maximally free. All workers were hired by contractors, who paid them in full every week. The company neither made nor demanded any longerterm commitments. It ensured its labor supply by paying a daily wage that was high enough to attract workers from surrounding areas. It supplied no schools, clinics, or family housing.

"Sustainable Palm Oil" Certification schemes that attempt to address unfair labor practices (and also unfair land acquisition, environmental damage, and other issues) stumble on the limits of the law. Insisting that companies obey the law accomplishes little where the law does not apply to casual workers, now the majority of Indonesia's plantation workforce. ${ }^{86}$ Risk to its global reputation notwithstanding, Wilmar International, one of the biggest transnational oil palm corporations and a member of the Round Table on Sustainable Oil Palm, has acknowledged that some of its plantations employ only 5-10 percent of the workforce on a permanent basis. ${ }^{87}$ Attempts to regulate by means of certification are further hampered by market conditions: corporations supplying the EU market may have an incentive to comply, but the market for uncertified cooking oil is massive, especially in India and China, and increasingly in Indonesia itself.

An important mode of regulation is that conducted by workers themselves, especially when they are organized. Recall that in Sumatra in the 1950s it was pressure from plantation workers' unions, not state or planter benevolence, that pushed back against planter attempts to replace permanent with casual workers and successfully extended worker protections. No doubt workers' gains diminished profit margins and contributed to the vicious attack against them in 1965. The New Order banned independent unions. The 2003 Labour Law restored the right to organize, but as noted, most workers fall outside its scope. Casual workers who organize are easily intimidated by company thugs or by the threat of being denied work. Attempts to rebuild plantation worker unions are still rudimentary and the obstacles are severe. The best protection for workers currently is their market value, hence skilled male migrant harvest workers are treated relatively well. If they strike or move away, leaving uncollected fruit to rot, the company immediately loses money. But local men, or men who are old or injured, are excluded from this form of protection. So too are landless women of any age whose commitments to anchoring families and maintaining the social infrastructure of community life keep them trapped in villages tucked around plantations.

limited-term contracts that specify pay and benefits, and could be used to make claims under the law (World Bank 2010: 56-61).

${ }^{86}$ McCarthy 2012; McCarthy and Zen 2010.

87 Milieudefensie, Lembaga Gemawan, and KONTAK Rakyat Borneo 2007: 41, 77, 89-90. 


\section{CONCLUSION}

Three questions guided my comparative inquiry in this essay: What were the conditions that led planters in Indonesia to rely on unfree labor in some cases, and "free" labor in others? What was the interplay between freedom and unfreedom in shaping the relations that emerged? And who took responsibility for ensuring social reproduction? Not surprisingly, I found that unfree workers lost out when they were prevented from selling their labor at the market price, but I emphasized how workers who must rely solely on markets to secure their daily and intergenerational reproduction are dangerously exposed. Indonesia's history of regulating the conditions of work for free and unfree labor over the past two centuries is a sorry one. Only for brief periods have worker pressure or state regulation obliged employers to take responsibility for the social reproduction of their work force. Concretely, I examined how tensions between freedom and unfreedom played out in a series of colonial and contemporary plantation labor regimes that took shape according to the contours of crops and technologies, employer practices, and economic and political contexts that empowered workers or employers in particular ways.

In colonial Java, workers were coerced into intensive coffee production without recompense and without regard for how or whether their subsistence needs were met. Authorities made the convenient assumption that unfree workers bound to landholder households were merely meeting their customary obligations, and landholders delivering forced coffee were entitled to no more than a "collection allowance." Yet Javanese farmers proved themselves more than willing to grow coffee independently whenever they were free to earn a fair price. The purpose of imposing unfree relations on workers and landholders was to extract monopoly profit, which the Dutch did successfully for more than a century. Eventually, however, excessive force, greed, and inattention to social and ecological limits pushed the coffee system into collapse.

In colonial Sumatra, indentured workers who were beaten and starved still yielded profits for tobacco planters, and when they died were readily replaced. No doubt indenture enabled and sanctioned these excessive and violent forms of abuse. But the main purpose of indenture contracts was to prevent workers from absconding to seek better wages elsewhere, or accessing land to farm independently. Planters abandoned indenture when it became unprofitable because the price of maintaining unfree workers, even at minimal levels, outweighed the profits. The switch to "free" labor was enabled by the shift from tobacco to rubber, which needs less labor, and by the emergence of a landless labor reserve. Ex-workers who had carved out spaces of autonomy in squatter settlements around the plantation edge in the 1940s and 1950s paid a price for their freedom because the residual patches of land they claimed were insufficient. Their children were obliged to seek casual work on plantations on 
precarious terms, which worsened in the 1970 s when oil palm replaced rubber and squeezed people out.

Making Sumatra's planters less free, by obliging them to take some responsibility for social reproduction, was the result of a hard struggle led by plantation workers' unions in the 1950s. After the eradication of the union and massacre of union members in 1965, state plantations were tasked with demonstrating the benefits of a military-led corporate-bureaucratic style of national development. They provided plantations workers with a full package of worker rights and family care, but only for a small core permanent workforce in Sumatra, and in Kalimantan only for one generation. Since 2003, state plantations have been free to hire and fire at will. As the example of a badly overgrown plantation confirmed, this kind of freedom imposes market discipline on not only workers but plantations as well.

"Free" workers have to be paid the going rate. Yet the rate is set by their market value, not by their needs, and the forms of discipline that operate under conditions of market freedom can be severe. Workers may be obliged to accept exhausting work that causes them injury and pain, and turns the workplace into a site of self-exploitation and the continuous calculation of risk. When the saturation of the land with plantations is sufficiently advanced to produce a proximate labor reserve, contemporary plantations in Kalimantan drive down the price of labor power by recruiting workers from two spatially distinct labor pools. They recruit harvesters from one sector of the population (young, male, migrant) and maintenance workers from another (female, local, landless). The outcome for workers is a double jeopardy: not only are plantations legally absolved from responsibility for the social reproduction of workers, but the fragmentation of families makes it very difficult for workers to take care of social reproduction for themselves.

New plantations on Kalimantan's still expanding frontier are not repeating the pattern of PTPN-ME of recruiting workers as families and providing good facilities to hold them in place. In the establishment phase, they work through contractors who entice workers with a relatively high wage and straight cash nexus. Once the palms are in production, plantations may attempt to recruit and hold a core of permanent workers, but the trajectories I have traced in Sumatra and Kalimantan suggest that the tide will turn against workers as the land becomes saturated with plantations and landless people must scramble to find work. ${ }^{88}$ It is technically possible for oil palm smallholders to match plantation productivity, but the lobby promoting corporate oil palm is intent on reaping monopoly profits, hence large-scale plantations are taking up more and more space. ${ }^{89}$

\footnotetext{
88 Relatively high wages and high worker turnover characterized the labor regime on a Kalimantan land frontier described by Potter (2012). I trace these intergenerational effects in more detail in Li (in press).

${ }^{89}$ Cramb and McCarthy 2016a.
} 
The current labor regime on Indonesia's oil palm plantations is largely free from regulation by state or worker pressure. It is so free it is vicious. People who sell their labor power "freely" to the point of exhaustion pay a high price in damaged bodies, fractured families, and a desperate struggle to meet quotas, find work, or simply to survive. The current labor regime is highly profitable for plantations, and shows no signs of driving them to the point of collapse. It would take a formidable countermovement to tame the planters' excess of freedom and put a protective labor regime in place.

\section{REFERENCES}

Accenture. 2012. Exploitative Labor Practices in the Global Palm Oil Industry. http:// humanityunited.org/pdfs/Modern_Slavery_in_the_Palm_Oil_Industry.pdf (accessed 9 Jan. 2017).

Alatas, Syed Hussein. 1977. The Myth of the Lazy Native: A Study of the Image of the Malays, Filipinos and Javanese from the 16th to the 20th Century and Its Function in the Ideology of Colonial Capitalism. London: Routledge.

Amnesty International. 2010. Trapped: The Exploitation of Migrant Workers in Malaysia. https:/www.amnesty.org/en/documents/ASA28/002/2010/en/ (accessed 9 Jan. 2017).

Anderson, Benedict. 1999. Indonesian Nationalism Today and in the Future. New Left Review 235: 3-17.

Aspinall, E. and G. van Klinken, eds. 2011. The State and Illegality in Indonesia. Leiden: KITLV.

Barlow, Colin. 1991. Developments in Plantation Agriculture and Smallholder CashCrop Production. In J. Hardjono, ed., Indonesia: Resources, Ecology, and Environment. Singapore: Oxford University Press.

Barral, Stephanie. 2014. Paternalistic Supervision of Labour in Indonesian Plantations: Between Dependence and Autonomy. Journal of Agrarian Change 14, 2: 240-59.

Behal, Rana P. 2014. One Hundred Years of Servitude: Political Economy of Tea Plantations in Colonial Assam. Delhi: Tulika Books.

Boomgaard, Peter. 2009. Labour, Land, and Capital Markets in Early Modern Southeast Asia from the Fifteenth to the Nineteenth Century. Continuity and Change 24, 1: 55-78.

Brass, Tom. 2010. Unfree Labour as Primitive Accumulation? Capital and Class 35, 1: 23-38.

Brass, Tom and Henry Bernstein. 1992. Introduction: Proletarianisation and Deproletarianisation on the Colonial Plantation. In E. V. Daniel, H. Bernstein, and T. Brass, eds., Plantations, Proletarians and Peasants in Colonial Asia. London: Frank Cass.

Breman, Jan. 1983. Control of Land and Labour in Colonial Java. Dordrecht: Foris Publications Holland.

Breman, Jan. 1989. Taming the Coolie Beast: Plantation Society and the Colonial Order in Southeast Asia. Delhi: Oxford University Press.

Breman, Jan. 2015. Mobilizing Labour for the Global Coffee Market: Profits from an Unfree Work Regime in Colonial Java. Amsterdam: Amsterdam University Press.

Breman, Jan and E. Valentine Daniel. 1992. Conclusion: The Making of a Coolie. In E. V. Daniel, H. Bernstein, and T. Brass, eds., Plantations, Proletarians and Peasants in Colonial Asia. London: Frank Cass.

Clarence-Smith, W. G. 1994. The Impact of Forced Coffee Cultivation on Java, 18051917. Indonesia Circle 64: 241-64. 
Cramb, Rob and John McCarthy. 2016a. Characterising Oil Palm Production in Indonesia and Malaysia. In R. Cramb and J. McCarthy, eds., The Oil Palm Complex: Smallholders, Agribusiness and the State in Indonesia and Malaysia. Singapore: NUS Press.

Cramb, Rob and John McCarthy, eds. 2016b. The Oil Palm Complex: Smallholders, Agribusiness and the State in Indonesia and Malaysia. Singapore: NUS Press.

Daniel, Valentine, Henry Bernstein, and Tom Brass, eds. 1992. Plantations, Proletarians and Peasants in Colonial Asia. London: Frank Cass.

Dove, Michael. 1999. Representations of the "Other" by Others: The Ethnographic Challenge Posed by Planters' Views of Peasants in Indonesia. In T. M.Li, ed., Transforming the Indonesian Uplands: Marginality, Power and Production. London: Routledge/ Harwood.

Dove, Michael. 2011. The Banana Tree at the Gate. New Haven: Yale University Press.

Elmhirst, Rebecca. 2011. Migrant Pathways to Resource Access in Lampung's Political Forest: Gender, Citizenship and Creative Conjugality. Geoforum 42: 173-83.

Elson, Robert. 1994. Village Java under the Cultivation System, 1830-1870. Sydney: Allen and Unwin.

Fernando, M. R. 2003. Coffee Cultivation in Java, 1830-1917. In W. G. ClarenceSmith, ed., The Global Coffee Economy in Africa, Asia, and Latin America 15001989. Cambridge: Cambridge University Press.

Ford, Michele. 1999. Testing the Limits of Corporatism: Industrial Relations in Suharto's Indonesia. Journal of Industrial Relations 41, 3: 372-92.

Fraser, Nancy. 2014. Can Society Be Commodities all the Way Down? Post-Polanyian Reflections on Capitalist Crisis. Economy and Society 43, 4: 541-58.

Goffman, Erving. 1961. Asylums. New York: Anchor Books.

Gordon, Alec. 1982. Indonesia, Plantations and the "Post-Colonial" Mode of Production. Journal of Contemporary Asia 12, 2: 168-87.

Houben, V.J.H. 1994. Profit versus Ethics: Government Enterprises in the Late Colonial State. In R. Cribb, ed., The Late Colonial State in Indonesia: Political and Economic Foundations of the Netherlands Indies 1880-1942. Leiden: KITLV Press.

Institut Analisa Sosial. 1989. Sucked Oranges: The Indian Poor in Malaysia. INSAN: Institut Analisa Sosial (Malaysia).

Institute for Ecosoc Rights. 2014. Industri Perkebunan Sawit dan Hak Asasi Manusia: Potret Pelaksanaan Tanggung Jawab Pemerintah dan Korporasi terhadap Hak Asasi Manusia de Kalimantan Tengah. Jakarta: Institute for Ecosoc Rights/Norwegian Center Human Rights.

International Labor Organization. 2013. Labour and Social Trends in Indonesia 2013: Reinforcing the Role of Decent Work in Equitable Growth. Jakarta: ILO.

Julia and Ben White. 2012. Gendered Experience of Dispossession: Oil Palm Expansion in a Dayak Hibun Community in West Kalimantan. Journal of Peasant Studies 39, 3-4: 995-1016.

Kano, Hiroyoshi. 2008. Indonesian Exports, Peasant Agriculture and the World Economy, 1850-2000. Athens: Ohio University Press.

Kaur, Amarjit. 2014. Plantation Systems, Labour Regimes and the State in Malaysia, 1900-2012. Journal of Agrarian Change 14, 2: 190-213.

Knight, G. R. 1988. Peasant Labour and Capitalist Production in Late Colonial Indonesia: The 'Campaign' at a North Java Sugar Factory 1840-70. Journal of Southeast Asian Studies 19, 2: 245-65.

Kompas. 1997. 'Koeli Kontrak' dan Warisannya (1): Lolos Akibat Perkembangan Ekonomi. Kompas, 10 Jan. 
LeBaron, Genevieve. 2015. Unfree Labour beyond Binaries. International Feminist Journal of Politics 17, 1: 1-19.

Li, Tania Murray. 2015. Social Impacts of Oil Palm in Indonesia: A Gendered Perspective from West Kalimantan. Bogor, Indonesia: Center for International Forestry Research (CIFOR).

Li, Tania Murray. 2016. Situating Transmigration in Indonesia's Oil Palm Labour Regime. In R. Cramb and J. McCarthy, eds., The Oil Palm Complex: Smallholders, Agribusiness and the State in Indonesia and Malaysia. Singapore: NUS Press.

Li, Tania Murray. In press. Intergenerational Displacement in Indonesia's Oil Palm Plantation Zone. Journal of Peasant Studies.

Li, Tania Murray, Alexandre Pelletier, and Arianto Sangadji. 2016. Unfree Labour and Extractive Regimes in Colonial Java and Beyond. Development and Change 47, 3: 598-611.

Lindquist, Johan. 2010. Labour Recruitment, Circuits of Capital and Gendered Mobility: Reconceptualizing the Indonesian Migration Industry. Asia Pacific Viewpoint 83, 1: $115-32$.

Lindquist, Johan. 2012. The Elementary School Teacher, the Thug and His Grandmother: Informal Brokers and Transnational Migration from Indonesia. Pacific Affairs 85, 1: 69-89.

Marti, Serge. 2008. Losing Ground: The Human Rights Impacts of Oil Palm Plantation Expansion in Indonesia: London, Edinburgh, and Bogor: Friends of the Earth, LifeMosaic, and Sawit Watch. At: http://www.foei.org/wp-content/uploads/2014/08/ losingground.pdf (accessed 12 Dec. 2016).

Marx, Karl. 1986. Capital: A Critique of Political Economy, Volume One. Moscow: Progress Publishers.

Mbembe, Achille. 2001. On the Postcolony. Berkeley: University of California Press.

McCarthy, John. 2012. Certifying in Contested Spaces: Private Regulation in Indonesian Forestry and Oil Palm. Third World Quarterly 33, 10: 1871-88.

McCarthy, John and Zahari Zen. 2010. Regulating the Oil Palm Boom: Assessing the Effectiveness of Environmental Governance Approaches to Agro-Industrial Pollution in Indonesia. Law and Policy 32, 1: 153-79.

McKeown, Adam. 2012. How the Box Became Black: Brokers and the Creation of the Free Migrant. Pacific Affairs 85, 1: 21-45.

Milieudefensie, Lembaga Gemawan, and KONTAK Rakyat Borneo. 2007. Policy, Practice, Pride and Prejudice: Review of Legal, Environmental and Social Practices of Oil Palm Plantation Companies of the Wilmar Group in Sambas District, West Kalimantan (Indonesia). Amsterdam: Mileudefensie.

Murray, Martin J. 1992. 'White Gold' or 'White Blood'? The Rubber Plantations of Colonial Indochina, 1910-40. Journal of Peasant Studies 19, 3-4: 41-67.

Pelzer, Karl J. 1978. Planter and Peasant: Colonial Policy and the Agrarian Struggle in East Sumatra 1863-1947. The Hague: Martinus Nijhoff.

Pelzer, Karl J. 1982. Planters against Peasants: The Agrarian Struggle in East Sumatra 1947-1958. The Hague: Martinus Nijhoff.

Polanyi, Karl. 1944. The Great Transformation. New York: Farrar \& Rinehart.

Potter, Lesley. 2012. New Transmigration 'Paradigm' in Indonesia: Examples from Kalimantan. Asia Pacific Viewpoint 53, 3: 272-87.

Pye, Oliver. 2015. Transnational Space and Workers' Struggles: Reshaping the Palm Oil Industry in Malaysia. In B. E. Kristina Dietz, Oliver Pye, and Achim Brunnengräber, eds., The Political Ecology of Agrofuels. London: Routledge. 
Pye, Oliver, Ramlah Daud, Yuyun Harmono, and Tatat. 2012. Precarious Lives: Transnational Biographies of Migrant Oil Palm Workers. Asia Pacific Viewpoint 53, 3: $330-42$.

Ramasamy, P. 1992. Labour Control and Labour Resistance in the Plantations of Colonial Malaya. In E. V. Daniel, H. Bernstein, and T. Brass, eds., Plantations, Proletarians and Peasants in Colonial Asia. London: Frank Cass.

Robertson, Philip S. 2008. Migrant Workers in Malaysia: Issues, Concerns and Points for Action. Washington, D.C.: Fair Labor Association.

Schrauwers, Albert. 2001. The "Benevolent" Colonies of Johannes van den Bosch: Continuities in the Administration of Poverty in the Netherlands and Indonesia. Comparative Studies in Society and History 43, 2: 298-328.

Schrauwers, Albert. 2011. Policing Production: Corporate Governmentality and the Cultivation System. Focaal 61: 75-90.

Schuster Institute. 2013. Palm Oil Controversies. Schuster Institute for Investigative Journalism. At: http://www.schusterinstituteinvestigations.org/\#!slavery-in-palm-oilindustry/cgit (accessed 28 Nov. 2016).

Siagian, Saurlin P., Amin Siahaan, Buyung, and Nur Khairani. 2011. The Loss of Reason: Human Rights Violations in the Oil Palm Plantations in Indonesia: Lentera-Brot fur die Welt. Study carried out on behalf of Lentera Rakyat, Indonesia, At: https://www.brot-fuer-die-welt.de/fileadmin/mediapool/2_Downloads/Fachinfor mationen/Aktuell/Aktuell_22_loss-of-reason.pdf (accessed 28 Nov. 2016).

Sinaga, Hariati. 2013. Employment and Income of Workers on Indonesian Oil Palm Plantations: Food Crisis at the Micro Level. Future of Food: Journal on Food, Agriculture and Society 1, 2: 64-78.

Sirait, Martua. 2009. Indigenous Peoples and Oil Palm Expansion in West Kalimantan, Indonesia. The Hague: Cordaid.

Situmorang, Manginar. 2010. Strengthening the Peasant and Plantation Workers' Movement in North Sumatra. Asia Monitor Resource Centre 74. At: www.amrc.org.hk/content/ strengthening-peasant-and-plantation-workers-movement-north-sumatra (accessed 28 Nov. 2016).

Stoler, Ann Laura. 1995. Capitalism and Confrontation in Sumatra's Plantation Belt, 1870-1979. Ann Arbor: University of Michigan Press.

Tenaga Kita and PAN. 2002. Poisoned and Silenced: A Study of Pesticide Poisoning in the Plantations. Penang: Pesticide Action Network. At: http://www.panap.net/en/p/ post/pesticides-info-database/2346 (accessed 28 Nov. 2016).

Tjandraningsih, Indrasari. 2012. State-Sponsored Precarious Work in Indonesia. American Behavioral Sciences 57, 4: 403-19.

Wakker, Eric. 2005. Greasy Palms: The Social and Ecological Impacts of Large Scale Oil Palm Plantation in Southeast Asia. London, Edinburgh, Bogor: Friends of the Earth.

White, Ben. 2015. Revelatory Crises on the Commodity Frontier: The 1930s Slump in the Netherlands Indies. Presented at the workshop "Global Capitalism and Commodity Frontiers: A Research Agenda," 4-5 Dec., Amsterdam.

White, Ben. 2016. Remembering the Indonesian Peasants' Front and Plantation Workers' Union (1945-1966). Journal of Peasant Studies 43, 1: 1-12.

World Bank. 2010. Indonesia Jobs Report: Towards Better Jobs and Security for All. Jakarta: World Bank. 
Abstract: Although often associated with colonial times, tropical plantations growing industrial crops such as rubber, sugar, and oil palm are once again expanding. They employ hundreds of thousands of workers, who still use remarkably basic tools. Flagging colonial continuities, labor activists campaign against the reemergence of unfree labor and "modern forms of slavery." Paradoxically, labor activists also highlight the opposite problem: the casualization of plantation work, as workers are hired daily and fired at will. Recognizing that both "free" and unfree labor regimes have a long history in Indonesia, and plantations have pivoted between these modes more than once, my study compares plantation labor regimes in the colonial, New Order, and "reform" periods (post-1998) to answer three questions. First, given that employers always want to access disciplined labor at the lowest possible price, what were the conditions that led employers to rely on unfree labor in some cases, and "free" labor in others? Second, to what extent was unfreedom imposed as a response to excessive freedom among workers and peasants? Third, how were the costs of social reproduction distributed between workers and employers, and what pressures from workers or regulators (state, colonial, transnational) affected this distribution? In addition to published sources, I draw on my ethnographic research in West Kalimantan (2010-2015) to explore contemporary experiences of un/freedom among workers on state and private oil palm plantations.

Key words: Indonesia, labor, slavery, colonialism, casualization, plantations, social reproduction, unions, oil palm, migration 